\title{
Surge ammonium uptake in macroalgae from a coral atoll
}

\author{
Varsha Raikar and Mohideen Wafar* \\ National Institute of Oceanography, Dona Paula, Goa 403004, India \\ *Corresponding author (wafar@nio.org)
}

\begin{abstract}
Surge (non-linear) uptake of ammonium, measured by incorporation of ${ }^{15} \mathrm{~N}$, was investigated in three species of macroalgae (Ulva lactuca Linnaeus (Chlorophyta), Soliera robusta (Greville) Kylin (Rhodophyta) and Dictyota dichotoma (Hudson) Lamouroux (Phaeophyta)) from Kavaratti atoll (Lakshadweep, India). Addition of ammonium (up to $20 \mu \mathrm{mol} \mathrm{L} \mathrm{L}^{-1}$ ) led to pronounced uptake within 4-6 min, with the amount of ammonium taken up during surge phase (<4 $\mathrm{min}$ ) accounting for from about half to 10 times that taken up during the remaining period of incubation (5-30 min). Amount of ammonium taken up during surge related linearly to the concentration of ammonium given. Surge uptake in dark was also substantial, averaging $80 \%$ of that in light. Capability for rapid uptake of pulses of ammonium released by heterotrophs during day or night could thus be an important mechanism of survival and proliferation of macroalgae in the $\mathrm{N}$ impoverished atoll waters.
\end{abstract}

KEYWORDS: surge uptake, macroalgae, ammonium, ${ }^{15} \mathrm{~N}$, coral reefs 


\section{Introduction}

Maintenance of high levels of biological productivity (up to several $\mathrm{gC} \mathrm{m}^{-2} \mathrm{~d}^{-1}$ ) (Crossland et al., 1991 ) by coral atolls in oligotrophic oceanic waters with low ambient concentrations of $\mathrm{N}$ nutrients (typically of the order of few hundreds of nmols of inorganic $\mathrm{N} \mathrm{L}^{-1}$ ) has been explained variously in the last 2-3 decades. As far as corals themselves are concerned, the high production could be maintained by a tight recycling of $\mathrm{N}$ between the coral and its zooxanthellae (Wafar et al., 1985). Most other autotrophs would have to depend on sources such as upwelling near the reef (Andrews and Gentien, 1982), endogenous upwelling within the reef frame (Rougerie and Wauthy, 1993), ground water seepage (Naim, 1993) and regeneration in sediments (Williams et al., 1985), besides nitrification in a range of animal-bacterial associations (Wafar et al., 1990; Corredor et al., 1988; Welsh and Castadelli, 2004). Besides these 'steady' fluxes, sporadic supply is also important for $\mathrm{N}$ economy of the reefs. For example, fish shoals migrating onto the reef could raise ambient ammonium concentrations in the vicinity of corals up to $0.9 \mu \mathrm{M}$ (Meyer et al., 1983) and area-specific $\mathrm{N}$ regeneration by actively feeding holothurians (Uthicke and Klumpp, 1998) could be in a range similar to that reported for nutrient fluxes in coral reefs.

The ability of autotrophs to capture the sporadic or pulse addition of $\mathrm{N}$ would, therefore, be critical for maintaining the high productivity of the reefs. This is especially true with macroalgal and seagrass assemblages on atolls that account often for as much as $50 \%$ (Qasim and Bhattathiri, 1971) of the total production (Qasim et al., 1972) of the reef ecosystem. N-starved algae are known, under experimental conditions, to take up more $\mathrm{N}$ than their immediate requirements (Rosenberg et al., 1984; Thomas and Harrison, 1987; Costanzo et al., 2000; Danilo and Yap, 2001). Such a transient or surge uptake capability in the case of macroalgae in coral reefs would confer on them a competitive advantage since they would be able to make complete use of nitrogen when provided with in excess as would happen with excretion by large heterotrophs in the vicinity. Notwithstanding this possibility, the potential for, and intensity of, surge uptake in macroalgae of atolls has received little attention so far, with the exception of one study (Schaffelke and Klumpp, 1998) where Sargassum from a fringing reef has been shown to respond with time-averaged increase in photosynthesis and growth following pulse addition of $\mathrm{N}$ and $\mathrm{P}$. However, this does not demonstrate how rapidly the algae could remove $\mathrm{N}$ from the medium in short term. 
In this work, rates of surge uptake of ammonium measured in 3 common species of macroalgae from the Kavaratti atoll in Lakshadweep archipelago, India are reported. Unlike in earlier studies (Danilo and Yap, 2001) where surge uptake was deduced from loss of $\mathrm{N}$ in the medium, here accumulation of ${ }^{15} \mathrm{~N}$ in the algal cells was measured.

\section{Materials and methods}

The algae - (Ulva lactuca Linnaeus (Chlorophyta), Soliera robusta (Greville) Kylin (Rhodophyta) and Dictyota dichotoma (Hudson) Lamouroux (Phaeophyta)) - growing just below the low tide level in the lagoon were removed with their holdfasts intact and brought to a shore laboratory where they were cleaned of epiphytes and sediments. They were then held, with aeration and in low light, in seawater collected from the sampling site and filtered through $0.45 \mu \mathrm{m}$ filter pads, for a few $\mathrm{h}$ before experimentation.

Uptake measurements were carried out with approximately $0.5 \mathrm{~g}$ of algal tissue placed in beakers with $250 \mathrm{ml}$ of seawater to which ammonium was added to give final concentrations of $2.5,5,10$ and $20 \mu \mathrm{mol} \mathrm{N} \mathrm{L}{ }^{-1}$. The required concentration of ammonium in each case was prepared by mixing 9 parts of unlabelled ammonium with 1 part of ${ }^{15} \mathrm{~N}$-labelled ammonium (99 atom \% excess). For each set of experiments with a given concentration, 16 incubations with algal tissues were prepared and spiked with ammonium. Incubations were carried out at a light intensity of $800 \mu \mathrm{E} \mathrm{m} \mathrm{m}^{-2} \mathrm{~s}^{-1}$ and at an ambient temperature of $27-28^{\circ} \mathrm{C}$. Duplicate sets of algal tissues were withdrawn at 0,2, 4, 6, 8, 10, 20 and 30 min after the beginning of the incubation (sampling for the algal tissue at 0 min was immediately after the addition of ammonium). Dark incubations were carried out in the same manner, with algal samples withdrawn at the same time intervals. The beakers were shaken periodically to prevent localized depletion of ammonium in the incubation medium.

Algal material removed from the incubation medium was briefly rinsed with deionized water and dried to a constant weight at $70^{\circ} \mathrm{C}$. Particulate organic nitrogen (PON) content of the algal tissues was determined by Kjeldahl digestion, steam distillation and titration with a normal solution of $\mathrm{NaOH}$ (precision $0.15 \mu \mathrm{mol} N$ ). At the end of the titration, the ammonium was trapped by acidification with a few drops of $0.05 \mathrm{~N} \mathrm{HCl}$, concentrated to a smaller volume, dried and taken for measurements of ${ }^{14} \mathrm{~N}$ : ${ }^{15} \mathrm{~N}$ isotopic ratios in a Jasco $\mathrm{N}-151$ Heavy Nitrogen analyzer. PON concentrations and isotopic ratios thus were obtained from the same sample and uptake rates were calculated with the equation (Dugdale and Wilkerson, 1986) where PON concentration at the end of the incubation is used. Control algal samples were used for the determination of natural abundance of ${ }^{15} \mathrm{~N}$. 
Ammonium concentrations of the seawater used for the incubations were measured by the indophenol blue method (Koroleff, 1970) in a Jasco UV-VIS spectrophotometer.

\section{Results}

Fig. 1 is a typical example of responses in uptake to addition of ammonium to levels $(2.5 \mu \mathrm{mol} N$ $\left.\mathrm{L}^{-1}\right)$ greater than ambient $\left(\sim 0.2-0.3 \mu \mathrm{mol} \mathrm{N} \mathrm{L^{-1 } )}\right.$ in all the 3 species. Uptake rates became pronounced within 4-6 min (surge uptake), with the amount of ammonium taken up during the surge (<4 $\mathrm{min}$ ) accounting for from about half to 10 times that taken up during the remaining period of incubation (5-30 $\mathrm{min}$ ) (Table 1). The amounts of ammonium taken up during the surge increased through a factor of 3-5 as a function of the concentration of ammonium added (Table 1). Expressed as rates of uptake, these were equivalent to a range of 128 to $334 \mu \mathrm{mol} N$ (g dry $\mathrm{wt})^{-1} \mathrm{~h}^{-1}$ for U. lactuca, 90 to $578 \mu \mathrm{mol} \mathrm{N}(\mathrm{g} \text { dry wt) })^{-1} \mathrm{~h}^{-1}$ for S. robusta and 104 to $353 \mu \mathrm{mol} \mathrm{N} \mathrm{(g}$ dry $w t)^{-1} h^{-1}$ for $D$. dichotoma. Separate measurements of ammonium uptake over a range (1 -

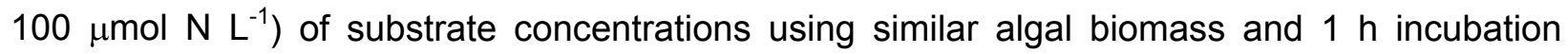
(unpublished data) gave maximum uptake rates $\left(\mathrm{V}_{\max }\right)$ of 65,31 and $69 \mu \mathrm{mol} \mathrm{N}\left(\mathrm{g}\right.$ dry wt) ${ }^{-1} \mathrm{~h}^{-1}$ respectively for $U$. lactuca, $S$. robusta and $D$. dichotoma). The surge uptake rates were generally greater by an order of magnitude in comparison with these substrate-saturable uptake rates as well.

Uptake of ammonium in dark was also pronounced during the surge phase (Fig. 2), though the absolute uptake rates at any given time, in comparison with those in light, were variable. Averaged over the 4 concentrations of ammonium tested, the ratios of dark to light uptake during surge phase were $0.7,0.75$ and 1 respectively for $U$. lactuca, $S$. robusta and $D$. dichotoma, suggesting that the ability of the algae to take up ammonium during surge is as significant in dark as in light. Average ratio of dark to light uptake from all measurements was $0.81 \pm 0.44$.

\section{Discussion}

Because of logistic constraints, samples were obtained only in duplicates. However, the data from 2 measurements did not differ by more than $10 \%$ and given the analytical precisions of the sample processing (wet oxidation and emission spectrometry), this is acceptable. The consistently high uptake rates in the initial phase $(<4 \mathrm{~min})$ in all experiments and the linear increase in surge uptake with the increase in ammonium concentration (Table 1) confirm, despite having only duplicates, the usefulness of the data. 
Non-linear uptake of ammonium when provided with in excess of immediate requirements has been shown in phytoplankton from nutrient-poor natural waters and $\mathrm{N}$-deficient culture media (Conway et al., 1976; Conway and Harrison, 1977; Harrison et al., 1989). This ability for rapid uptake of ammonium, in dark as well as in light (Packard, 1979), enables phytoplankton to grow at rates close to their maximum potential in N-impoverished waters (Goldman and Glibert, 1982). The extent of departure from linear uptake is therefore a measure of the degree of $\mathrm{N}$ limitation.

Macroalgae, because of their proximity to sites of ex-situ nutrient supply (land sources) or regeneration (benthic sediments), could generally be regarded as less $\mathrm{N}$-limited than phytoplankton. Nonetheless, transient rapid uptake of ammonium has been observed in algae grown in cultures or collected from natural habitats. Neoagardhiella baileyi and Gracilaria foliifera, grown under severe $\mathrm{N}$-limitation, took up ammonium in the first 5 minutes at rates nearly twice higher than later (D'Elia and DeBoer, 1978). Ammonium uptake in cultured brown seaweeds (Chordaria flagelliformis and Fucus distichus) was non-linear in the first $30 \mathrm{~min}$ at

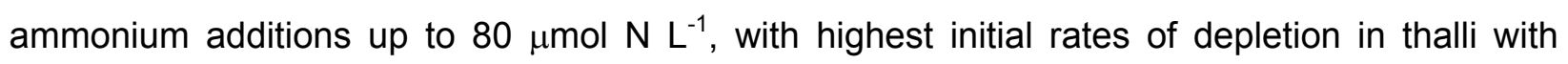
lowest $\mathrm{N}$ content (Rosenberg et al., 1984). Measurements with algae from field follow this pattern. A rapid ammonium uptake in 4 intertidal algae from British Columbia (Thomas and Harrison, 1987) was seen in the first $15 \mathrm{~min}$ after exposure to $15 \mu \mathrm{mol} \mathrm{NH}_{4} \mathrm{~L}^{-1}$. Ulva lactuca from Roskilde Fjord showed highest ammonium uptake within $15 \mathrm{~min}$ of incubations at substrate concentrations $>10 \mu \mathrm{mol} \mathrm{N} \mathrm{L}{ }^{-1}$, with the initial rate of surge uptake increasing as the function of nitrogen limitation (Pedersen, 1994). In Kappaphycus alvarezii ammonium uptake tended to be higher with higher initial ammonium concentration (Danilo and Yap, 2001) and there were no significant differences between uptake in light and dark in at least one concentration (30 $\mu \mathrm{mol} N$ $\mathrm{L}^{-1}$ ). More recently, it has been shown that ammonium uptake within the first 15 min was significantly higher than later (beyond $60 \mathrm{~m}$ ) in intertidal algae from southeastern Australia (Campbell, 1999) and New Zealand (Phillips and Hurd, 2003). In all these studies, cell quota of $\mathrm{N}$ and high $\mathrm{C}: \mathrm{N}$ ratios were determinants for the strength of surge uptake. For example, decrease in cell $\mathrm{N}$ quota from 4 to $2 \%$ caused a $2-4$ fold increase in surge uptake in Chordaria flagelliformis and Fucus distichus (Rosenberg et al., 1984). Low ambient concentrations could also be important: field data, where available (Danilo and Yap, 2001; Phillips and Hurd, 2003), show that ambient ammonium concentrations were generally $<2 \mu \mathrm{mol} \mathrm{N} \mathrm{L}{ }^{-1}$.

What is interesting in our results is not surge uptake per se but its strength. The initial uptake rates are several times higher than those reported in most other algae (see above), probably with the exception of Ulva lactuca where the surge uptake rate measured (D'Elia and DeBoer, 
1978) is comparable to our data. Besides, ratios of uptake during surge to uptake post-surge are quite high, up to 10 . Such high surge uptake rates can only partially be explained by low cell N quota (Fujita et al., 1988; McGlathery et al., 1996). Surge uptake measured in Chordaria flagelliformis and Fucus distichus with a cell $\mathrm{N}$ quota of $1 \%$ (Rosenberg et al., 1984) was still much less than in our study where the tissue $\mathrm{N}$ quota varied between 1.4 and $2.8 \%$. It is likely, therefore, that oligotrophy is an equally important cause of high surge uptake. Atoll waters are extremely poor in dissolved inorganic $\mathrm{N}$ and the ammonium concentrations in Kavaratti atoll (and elsewhere in the Lakshadweep atolls) are often below limits of detection. By contrast, ambient ammonium concentrations, where available in similar studies (Danilo and Yap, 2001; Phillips and Hurd, 2003), were between 1 and $2 \mu \mathrm{mol} \mathrm{N} \mathrm{L}{ }^{-1}$ or even greater (Campbell, 1999).

The quantity of ammonium taken up by $U$. lactuca during surge (Fig. 1) was at an intermediate level between those taken up by $S$. robusta and $D$. dichotoma. This does not agree with the generally held notion that $U$. lactuca is an opportunistic and ephemeral species, responding fast to nutrient enrichment. This, and the fact that the maximum of the ratios of ammonium assimilated between $<4$ and $<30$ min incubations was similar $(0.8$ to 0.9$)$ for all the 3 species (Table 1), add support to the conclusion that it could be rather the degree of oligotrophy, than phylogeny, that determines the intensity of surge uptake.

Though surge uptake of ammonium is not frequently measured, it could be an important mechanism of $\mathrm{N}$ acquisition for macroalgae in nutrient-poor reef waters given the diversity of heterotrophs habiting on them and in the vicinity. Seaweed surfaces are inhabited by a large number of small mobile and sessile organisms (Seed, 1986) and their excretion, as was shown in the case of epifauna on Carpophyllum plumosum (Taylor and Rees, 1998), is an important source of $\mathrm{N}$ for the alga. Other examples include fish shoals (Meyer et al., 1983), bryophyte colonies associated with Agarum fimbriatum and Macrocystis integrifolia (Hurd et al., 1994) amphipods and gastropods associated with Enteromorpha intestinalis (Barr and Rees, 2003), echinoderms (Danilo and Yap, 2001) and the sponge Haliclona cymiformis symbiotic with Ceratodictyon spongiosum (Davy et al., 2002). While a physically close association, as was the case in the symbiosis between C. spongiosum and H. cymiformis (Davy et al., 2002), may provide all of or more than the quantity of $\mathrm{N}$ required by the alga, removal by dilution (Taylor and Rees, 1998) could substantially reduce the amount of $N$ that actually becomes available to the alga from the heterotrophs. Efficient acquisition of $\mathrm{N}$ from heterotrophic sources thus would depend not on the release rates but rather on the rapidity of uptake. In this context, the ability of algae to maintain surge uptake rates as high in dark as in light (Fig. 2) would confer on them an ecological advantage since heterotrophic regeneration of ammonium is light-independent. As 
seen from the high surge uptake rates measured both in light and dark in our study, the macroalga from the atoll reefs would seem to be better adapted than others from elsewhere to acquire $\mathrm{N}$ efficiently.

\section{Acknowledgements}

One of us (VR) is thankful to the Council of Scientific and Industrial Research, India for a Senior Research Fellowship. Mr. T. P. Amanullah helped with the collection of algae. We are grateful for the constructive comments from two anonymous reviewers. This is contribution number 4162 from NIO, Goa. 


\section{References}

Andrews, J. C., Gentien, P., 1982. Upwelling as a source of nutrients for the Great Barrier Reef Ecosystems: A solution to Darwin's question? Marine Ecology Progress Series 8, 257-269.

Barr, N. G., Rees, T. A., 2003. Nitrogen status and metabolism in the green seaweed Enteromorpha intestinalis: an examination of three natural populations. Marine Ecology Progress Series 249,133-144.

Campbell, S. J., 1999. Uptake of ammonium by four species of macroalgae in Port Phillip Bay, Victoria, Australia. Marine and Freshwater Research 50, 515-522.

Conway, H. L., Harrison, P. J., 1977. Marine diatoms grown in chemostats under silicate or ammonium limitation. IV. Transient response of Chaetoceros debilis, Skeletonema costatum and Thalassiosira gravida to a single addition of the limiting nutrient. Marine Biology 43, 33-43.

Conway, H. L., Harrison, P. J., Davis, C. O., 1976. Marine diatoms grown in chemostats

under silicate or ammonium limitation. II. Transient response of Skeletonema costatum to single addition of the limiting nutrient. Marine Biology 35, 187-99.

Corredor, J.E., Wilkinson, C. R., Vicente, V.P., Morell, J. M., Otero, E., 1988. Nitrate release by Caribbean reef sponges. Limnology and Oceanography 33, 114-120.

Costanzo, S.D., O'Donohue, M.J., Dennison, W.C., 2000. Gracilaria edulis (Rhodophyta) as a biological indicator of pulsed nutrients in oligotrophic waters. Journal of Phycology 36, 680-685.

Crossland, C.J., Hatcher, B.G., Smith, S.V., 1991. Role of coral reefs in global ocean production. Coral Reefs 10, 55-64.

Danilo, Dy. T., Yap, H.T., 2001. Surge ammonium uptake of the cultured seaweed, Kappaphycus alvarezii (Doty) Doty (Rhodophyta: Gigartinales). Journal of Experimental Marine Biology and Ecology 265, 89-100.

Davy, K. S., Trautman, D.A., Borowitzka, M.A. and Hinde, R., 2002. Ammonium excretion by a symbiotic sponge supplies the nitrogen requirements of its rhodophyte partner. Journal of Experimental Biology 205, 3505-3511. 
D'Elia, C. F., DeBoer, J. A., 1978. Nutritional studies of two red algae. II. Kinetics of ammonium and nitrate uptake. Journal of Phycology 14, 266-272.

Dugdale, R.C., Wilkerson, F.P., 1986. The use of ${ }^{15} \mathrm{~N}$ to measure nitrogen uptake in eutrophic oceans, experimental considerations. Limnology and Oceanography 31, 673- 689.

Fujita, R. M., Wheeler, P. A., Edwards, R. L., 1988. Metabolic regulation of ammonium uptake by Ulva rigida (Chlorophyta): a compartmental analysis of the rate limiting step for uptake. Journal of Phycology 24, 560-6.

Goldman, J. C., Glibert, P. M., 1982. Comparative rapid ammonium uptake by four species of marine phytoplankton. Limnology and Oceanography 27, 814-27.

Harrison, P. J., Parslow, J. S., Conway, H. L., 1989. Determination of nutrient uptake Kinetic parameters: a comparison of methods. Marine Ecology Progress Series 52, 301- 312.

Hurd, C.L., Durante, K.M., Chia, F.S. and Harrison, P.J., 1994. Effect of bryozoan colonization on inorganic nitrogen acquisition by the kelps Agarum fimbriatum and Macrocystis integrifolia. Marine Biology 121,167-173.

Koroleff, F., 1970. Direct determination of ammonia in natural waters as indophenol blue. In: Information on techniques and methods for seawater. Interlaboratory Repor of Conseil International Pour L'exploration de la Mer 3,19-22.

McGlathery, k. J., Pedersen, M. F., Borum, J., 1996. Changes in intracellular nitrogen pools and feedback controls on nitrogen uptake in Cahetomorpha linum (Chlorophyta). Journal of Phycology, 1996, 32, 393-401.

Meyer, J. L., Schultz, E. T., Helfman, G.S., 1983. Fish schools: An asset to corals. Science 220,1047- 1049 .

Naim, O., 1993. Seasonal responses of a fringing reef community to eutrophication (Reunion Island, Western Indian Ocean). Marine Ecology Progress Series 99,137- 151.

Packard, T. T., 1979. Respiration and respiratory electron transport activity in plankton from the northwest African upwelling area. Journal of Marine Research 37, 711-742. 
Pedersen, M. F., 1994. Transient Ammonium uptake in the macroalga Ulva lactuca (Chlorophyta): Nature, regulation, and the consequences for choice of measuring technique. Journal of Phycology 30, 980-986.

Phillips, J.C., Hurd, C.L., 2003. Nitrogen ecophysiology of intertidal seaweeds from New Zealand: $\mathrm{N}$ uptake, storage and utilization in relation to shore position and season. Marine Ecology Progress Series 264, 31-48.

Qasim, S. Z. and Bhattathiri, P. M. A., 1971. Primary production of a seagrass bed on Kavaratti Atoll (Laccadives). Hydrobiologia, 38, 29-38.

Qasim, S. Z. and Bhattathiri, P. M. A., Reddy, C. V. G., 1972. Primary production of an atoll in the Laccadives. Int. Revue. Ges. Hydrobiol., 57, 207-225.

Rosenberg, G., Probyn, T.A., Mann, K. H., 1984. Nutrient uptake and growth kinetics in brown seaweeds: Response to continuous and single additions of ammonium. Journal of Experimental Marine Biology and Ecology 80,125- 146.

Rougerie, F., Wauthy, B., 1993. The endo-upwelling concept: From geothermal convection to reef construction. Coral Reefs 12, 19-30.

Schaffelke, B., Klumpp, D.W., 1998. Short-term nutrient pulses enhance growth and photosynthesis of the coral reef macroalgae Sargassum baccularia. Marine Ecology Progress Series 170, 95-105.

Seed, R., 1986. Ecological pattern in the epifaunal communities of coastal macroalgae. in :The ecology of rocky coasts (eds. Moore, P. G. and Seed, R.) Columbia University Press, New York 22-35.

Taylor, R. B., Rees, T. A., 1998. Excretory products of mobile epifauna as a nitrogen source for seaweeds. Limnology and Oceanography 43, 600-606.

Thomas, T. E., Harrison, P. J., 1987. Rapid ammonium uptake and nitrogen interactions in five intertidal seaweeds grown under field conditions. Journal of Experimental Marine Biology and Ecology 107, 1-8.

Uthicke,S., Klumpp, D.W., 1998. Microbenthos community production in sediments of a near shore coral reef: seasonal variation and response to in situ nutrient enhancement. Marine Ecology Progress Series 169,1-11. 
Wafar, M., Wafar, S., David, J.J., 1990. Nitrification in reef corals. Limnology and Oceanography $35,725-730$.

Wafar, M.V.M., Devassy, V.P., Slawyk, G., Goès, J., Jayakumar, A., Rajendran, A.,1985. Nitrogen uptake by phytoplankton and zooxanthellae in a coral atoll. Proceedings of 5th International Coral Reef Congress 6, 29-37.

Welsh, W.T., Castadelli, G., 2004. Bacterial nitrification activity directly associated with isolated benthic marine animals. Marine Biology 144, 1029-1037.

Williams, S.L., Yarish, S.M., Gill, I.P., 1985. Ammonium distributions, production and efflux from backreef sediments, St. Croix, US Virgin Islands. Marine Ecology Progress Series 24, 57-64. 
Table 1: Amount of ammonium-N incorporated ( $\mu \mathrm{mol} \mathrm{g}^{-1} \mathrm{DW}$ ) incorporated after 4 min and 30 min of incubation with different concentrations of ammonium.

\begin{tabular}{|l|c|c|c|c|}
\hline \multirow{2}{*}{ Species } & \multicolumn{4}{|c|}{ Ammonium concentration $\left(\mu \mathrm{mol} \mathrm{L}^{-1}\right)$} \\
\hline & 2.5 & 5 & 10 & 20 \\
\hline U. lactuca & & & 22.3 & 8.6 \\
\hline $0-4$ min & 8.5 & 12.0 & 31.0 & 16.4 \\
\hline $0-30$ & 10.4 & 30.9 & & \\
\hline & & & 16.7 & 38.5 \\
\hline S. robusta & 6.0 & 16.8 & 25.6 & 48.1 \\
\hline $0-4$ min & 10.5 & 52.4 & & \\
\hline $0-30$ & & & 11.0 & 23.5 \\
\hline D. dichotoma & 20.8 & 6.9 & 70.6 & \\
\hline $0-4$ min & 31.9 & 7.6 & & \\
\hline $0-30$ & & & & \\
\hline
\end{tabular}




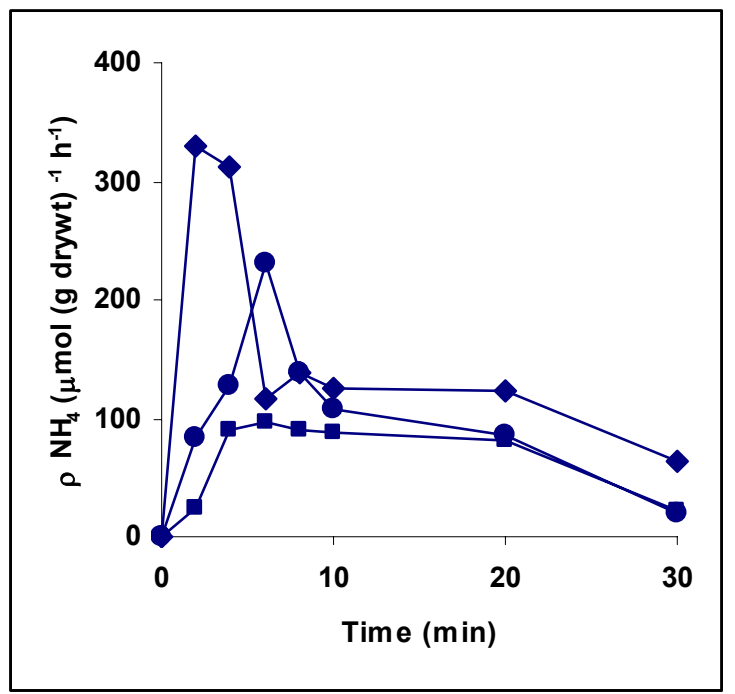

Figure 1: Time series changes of ammonium uptake rates in response to addition of ammonium at $2.5 \mu \mathrm{mol} \mathrm{N} \mathrm{L} \mathrm{N}^{-1}$ above ambient. U. lactuca (closed circle), S. robusta (square) and $D$. dichotoma (diamond).

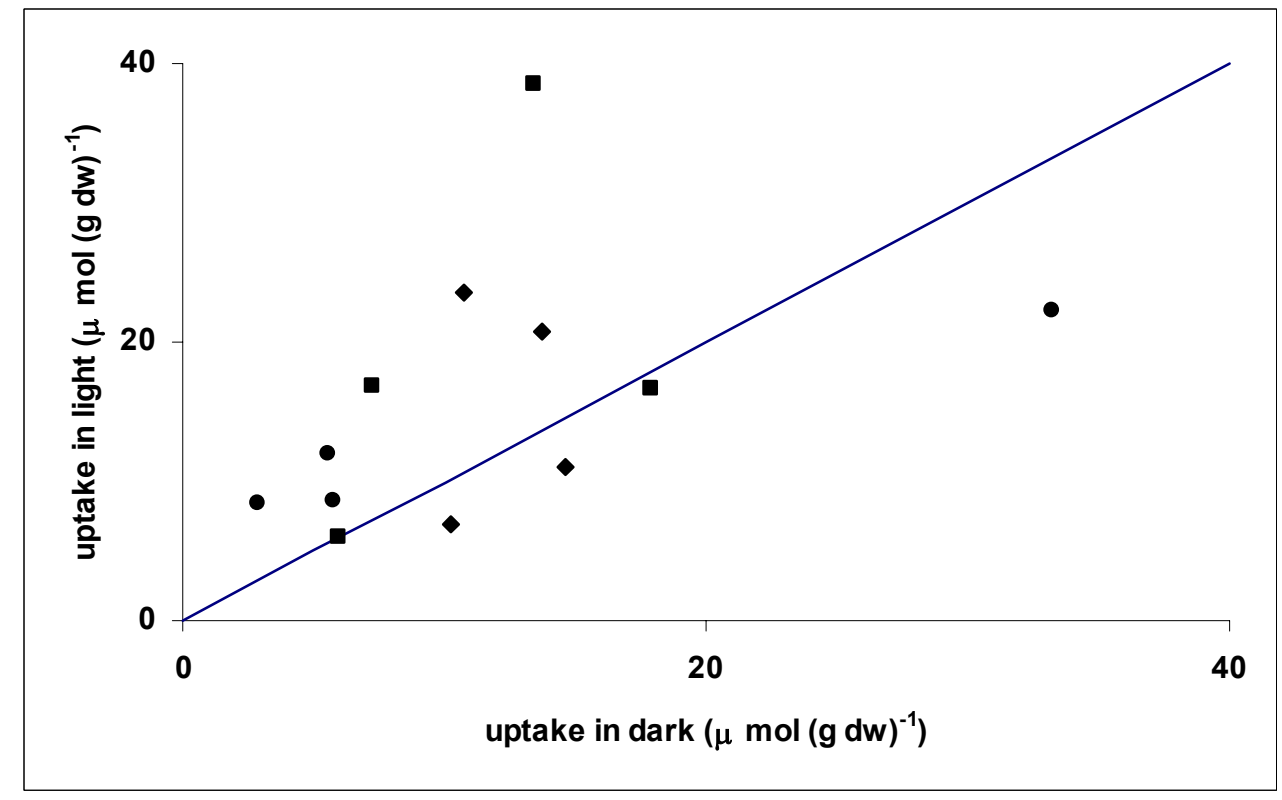

Figure 2: Relationship between ammonium taken up during surge in light and dark at different concentrations of ammonium. U. lactuca (closed circle), S. robusta (square) and D. dichotoma (diamond). The 1:1 line shown to demonstrate the importance of dark uptake. 